\title{
Abundance and diversity of coastal fish larvae as indicators of recent changes in ocean and climate conditions in the Oregon upwelling zone
}

\author{
Richard D. Brodeur ${ }^{1, *}$, William T. Peterson ${ }^{1}$, Toby D. Auth ${ }^{2}$, Heather L. Soulen ${ }^{2,4}$, \\ Maria M. Parnel ${ }^{2,5}$, Ashley A. Emerson ${ }^{3}$ \\ ${ }^{1}$ Northwest Fisheries Science Center, NOAA Fisheries, Newport, Oregon 97365, USA \\ ${ }^{2}$ Cooperative Institute for Marine Resources Studies, Oregon State University, Newport, Oregon 97365, USA \\ ${ }^{3}$ Northern Arizona University, Flagstaff, Arizona 86011, USA \\ ${ }^{4}$ Present address: Smithsonian Environmental Research Center, PO Box 28, 647 Contees Wharf Road, Edgewater, \\ Maryland 21037, USA \\ ${ }^{5}$ Present address: Washington Department of Fish and Wildlife, 600 Capitol Way North, \\ Olympia, Washington 98501, USA
}

\begin{abstract}
We examined ichthyoplankton sampled from 2 stations, 9 and $18 \mathrm{~km}$ offshore of Newport, Oregon, USA, over a decade of cruises every 2 wk from 1996 to 2005. The 10 most dominant taxa comprised approximately $87.3 \%$ of the total catch. Concentration of fish larvae was highest in January to March, whereas diversity peaked from March through May. Both overall diversity and density of larval fishes were relatively constant throughout the period of 1996 to 2003 , with a dramatic decrease in these metrics since 2004, especially for winter-spawning (January-May) species. During cool years (1999-2002), the assemblage was dominated by northern or coastal taxa such as sand lance Ammodytes hexapterus, sanddabs Citharichthys spp., and smelts Osmeridae, whereas in warm years (2003-2005), southern or offshore taxa such as English sole Parophrys vetulus, northern anchovy Engraulis mordax, and rockfishes Sebastes spp. were more abundant. These changes were related to concurrent shifts in the zooplankton biomass and composition off Oregon during cold and warm environmental regimes. We have identified a small subset of fish whose larvae can be monitored as indicators of warm and cold phases in the northeast Pacific Ocean.
\end{abstract}

KEY WORDS: Larval fish - Density - Diversity · Temporal variability · Upwelling ecosystem • California Current

Resale or republication not permitted without written consent of the publisher

\section{INTRODUCTION}

Examining the effects of climate on recruitment and population dynamics of marine fish has been an area of active research over the last several decades (Cushing 1982, Fogarty 1993, McGinn 2002). Although many of the large marine ecosystems worldwide have been the focus of intense sampling in terms of their ichthyoplankton composition (e.g. Sherman et al. 1983), the mechanisms by which climate change leads to recruitment variation and ecosystem response are not fully understood. Larval-stage dynamics may be used as early indicators of future recruitment potential in adult fish stocks, and can, at times, provide leading indicators of spawning success or failure (Houde 1997, Hsieh et al. 2006). Moreover, egg and larval production can be related to spawning-stock biomass for many pelagic spawners (Lasker 1985, Hunter \& Lo 1993, Ralston et al. 2003). Finally, examination of longterm trends in ichthyoplankton populations can also 
provide information on the relative effects of climate and fishing on marine fish populations (Hsieh et al. 2005).

Ichthyoplankton collections were made from sampling every 2 wk along the Newport Hydrographic (NH) line off Newport, Oregon from 1996 to 2005. This period witnessed dramatic and perhaps unprecedented change in climate, ocean dynamics, and biological communities (Peterson \& Schwing 2003, Brodeur et al. 2005, Hooff \& Peterson 2006). The timing of these ichthyoplankton collections coincided with a wide variety of environmental conditions (e.g. warm and cool climate regimes, El Niño and La Niña events, and extended periods of positive and negative upwelling). This makes these data particularly suitable and valuable for evaluating changes in ichthyoplankton abundance relative to a fluctuating environment. The $\mathrm{NH}$ line was sampled intensively in the 1970s and 1980s (Richardson \& Pearcy 1977, Mundy 1984, Boehlert et al. 1985, Brodeur et al. 1985, Doyle et al. 1993, 2002), so substantial historical data exists during different oceanographic regimes with which to compare our data.

The purposes of this study are to: (1) identify and compare larval fish concentration and community structure from samples collected at 2 nearshore stations off the central Oregon coast to test for annual, seasonal, and monthly differences; (2) compare and contrast these findings to those of similar historical studies along the NH line; and (3) relate the larval communities to fluctuating marine environmental conditions observed in this dynamic upwelling region. We assessed trends in larval concentrations and diversity indices using cluster, multivariate, and indicator species analyses to identify and compare annual, seasonal, and monthly taxonomic assemblages. Through the analysis of this comparatively long time series of data, we hope to provide insight into larval fish dynamics on a small spatial scale, which may be used to forecast impacts of climate change on future species composition in the northern California Current.

\section{MATERIALS AND METHODS}

Sampling procedures. Ichthyoplankton samples were collected every 2 wk from December 1996 to December 2005 at 2 shelf stations along the $\mathrm{NH}$ line (NH-05: $44.65^{\circ} \mathrm{N}, 124.17^{\circ} \mathrm{W}$; and $\mathrm{NH}-10: 44.65^{\circ} \mathrm{N}$, $124.29^{\circ} \mathrm{W}$ ) located 9 and $18 \mathrm{~km}$ with bottom depths of 62 and $82 \mathrm{~m}$, respectively, off the central Oregon coast (Fig. 1). Although data were available from other stations extending beyond the shelf break on this line, we concentrated our analysis on the 2 inshore stations known to have a characteristic coastal assemblage (Richardson \& Pearcy 1977, Doyle et al. 2002, Auth \&

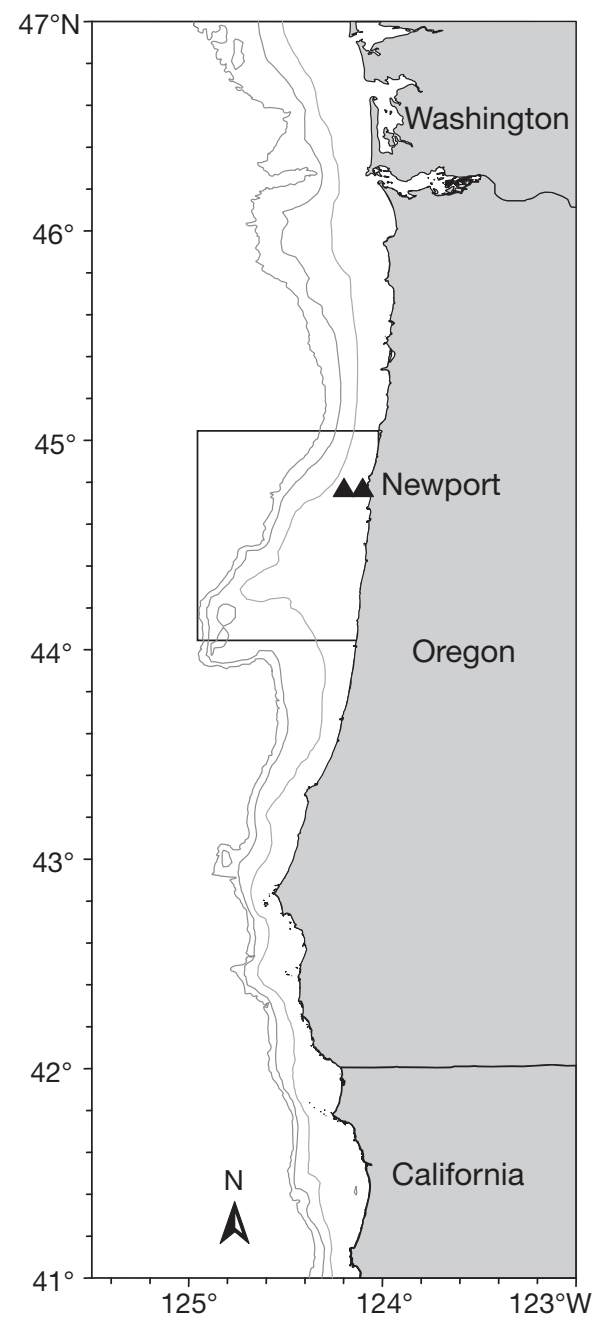

Fig. 1. Study area showing locations of long-term sampling (ム) and area where the temperature index was derived (box). Also shown are the 100,150, and $200 \mathrm{~m}$ isobaths

Brodeur 2006) so as to minimize spatial variability. Ichthyoplankton were collected with either a $1 \mathrm{~m}$ diameter ring net with $333 \mu \mathrm{m}$ or a $60 \mathrm{~cm}$ diameter bongo net with $200 \mu \mathrm{m}$ mesh nets. The mesh size on the bongo net was switched to $333 \mu \mathrm{m}$ mesh near the end of the time series, in April 2005. All tows (258 in total, $29 \%$ taken at night) were oblique within the upper $20 \mathrm{~m}$ of the water column. All fish larvae were sorted in the laboratory and identified to the lowest possible taxon. In some cases, our knowledge of the taxonomy of individual groups is incomplete (e.g. Osmeridae, Liparidae, Scorpaenidae), in which case we were able to identify larvae only to family or genus.

Seawater samples for chlorophyll a (chl a) analysis were collected with a bucket, and a $100 \mathrm{ml}$ subsample from each bucket was filtered through a glass-fiber GF/F filter and frozen for later analysis following extraction in $90 \%$ acetone for $24 \mathrm{~h}$ in the dark. Fluores- 
cence of the acetone extract was determined using a Turner Designs Model 10-AU fluorometer. Zooplankton were sampled with a $0.5 \mathrm{~m}$ diameter, $202 \mu \mathrm{m}$ mesh net towed vertically from $2 \mathrm{~m}$ off the sea floor to the surface. Sample processing was as described in Peterson \& Keister (2003) and Hooff \& Peterson (2006), with all copepods enumerated by species and developmental stage. Copepod biomass was calculated by multiplying species and stage abundances (no. $\mathrm{m}^{-3}$ ) by the weight of each developmental stage. Biomass anomalies were calculated based on the base period of samples collected in 1970-1973, 1983, and 1996-2004 for species grouped as 'cold-water species' and 'warmwater species' (Peterson \& Keister 2003). Cold-water species are boreal/subarctic in origin (Pseudocalanus mimus, Calanus marshallae, and Acartia longiremis), whereas warm-water species are either subtropical neritic or northern California Current/offshore species (Mesocalanus tenuicornis, Paracalanus parvus, Calocalanus styliremis, 3 species of Clausocalanus [C. pergens, C. parapergens, and C. arcuicornis], and Corycaeus anglicus).

Data analyses. For overall density (no. $\mathrm{m}^{-3}$ ) and diversity calculations, we examined the 2 stations separately. Multiple cruises within a month were averaged to provide a single monthly value of density or diversity. Biodiversity was calculated using the Shannon-Wiener diversity index $\left(H^{\prime}\right)$ using the proportional abundance by month. This index is:

$$
H^{\prime}=\sum-p_{i}\left(\ln p_{i}\right)
$$

where $p_{i}$ is the proportional abundance of taxon $i$.

Cluster analysis using Bray-Curtis similarities and a flexible beta ( $\beta=-0.25$ ) linkage strategy was conducted on the $4^{\text {th }}$-root transformed monthly totals of all taxa that occurred in at least $5 \%$ of the samples (24 taxa in total). Cluster analysis was also performed by month for all months that contained larvae (84 months in total) to determine which months were most similar in composition.

We used the non-parametric Multi-Response Permutation Procedure (MRPP; McCune \& Mefford 1999) to test for differences in dominant larval composition, and Indicator Species Analysis (ISA; Dufrene \& Legendre 1997) to determine which taxa were indicative of the various levels within each factor (station, regime, year, month, and season). MRPP tests within- and betweengroup differences by calculating an A-statistic that ranges from 0 (no agreement between groups) to 1 (complete agreement). ISA examines the fidelity of occurrence of a taxon within a particular group, which is based on the combined proportional measurements of the abundance of each particular taxon in a group relative to its abundance in all groups, and the percent frequency of that taxon in each group. The statistical significance of each group is examined by a Monte
Carlo method, in which sample units are randomly reassigned $\mathrm{n}$ times to test if the indicator species values are higher than would be expected by chance. For this study, 1000 runs were applied to each Monte Carlo simulation. All community analyses were performed using PC-Ord software (McCune \& Mefford 1999).

To examine the environmental conditions during which we did our sampling, we examined 4 indices. First, we examined 2 large-scale indices: (1) the Pacific Decadal Oscillation (PDO; http://jisao.washington. edu/pdo/PDO.latest) and the Multivariate El NiñoSouthern Oscillation Index (MEI; www.cdc.noaa.gov/ people/klaus.wolter/MEI). We also examined 2 more regional indices that represented conditions in the general area of sampling. First we included the anomalies from long-term (1967-2006) climatology of the Upwelling Index at $45^{\circ} \mathrm{N}, 125^{\circ} \mathrm{W}$ (UI; www.pfeg.noaa. gov/products/PFEL/modeled/indices/upwelling/). Secondly, sea surface temperature (SST) anomalies (baseline 1970-2006) from a $1^{\circ} \times 1^{\circ}$ square area near our sampling stations (Fig. 1) were derived from the International Comprehensive Ocean-Atmosphere Data Set (ICO ADS; www.cdc.noaa.gov/cgi-bin/Timeseries/ timeseries1.pl).

Non-metric multidimensional scaling (NMS) was used to further examine the community structure and relate it to environmental gradients. Distances between points were computed with a Sørensen (Bray-Curtis) distance measure. For this analysis, the same species by hauls matrices used in cluster analysis formed the main matrix. Relativized anomalies of the PDO, MEI, SST, and UI were used in complementary environmental data matrices. Initially, NMS were processed through 400 maximum iterations, 40 real runs, and 50 randomized runs (McCune \& Grace 2002). The decrease in stress with the addition of each ordination axis was examined, and selection of the final dimension was based on when stress reductions became small (McCune \& Grace 2002). Two dimensions were found to be appropriate for explaining variation (83.6\% of the total) in the original data. The final ordination was then generated on 2 dimensions and the best starting configuration. Finally, the 4 environmental variables identified in the previous paragraph were correlated with these 2 NMS axes and were displayed as vectors on the ordination plots.

\section{RESULTS}

\section{Environmental conditions}

Environmental conditions were highly variable during our sampling period, including strong (1998) and weak (2003) El Niño conditions, a strong La Niña (1999), reversals of the PDO index in 1999 and 2002, 
and both strong and weak upwelling and downwelling periods (Fig. 2). Sea surface temperatures were relatively warm in 1997 and 1998, cool from 1999 to 2002, and warm again thereafter (Fig. 2).

\section{Diversity and abundance}

A total of 5301 larvae in 70 taxa were identified from collections taken during this survey (Table 1), with an additional 80 larvae that were too damaged to identify. Pleuronectidae (flounders) and Cottidae (sculpins) were the most diverse families represented, with 14 and 13 distinct taxa present, respectively. Averaged over all samples, larval density was highest in winter (January-March), although October and November had comparable values to March at NH-05 (Fig. 3). Overall density and diversity were higher at NH-05 than NH-10, but neither parameter was significantly different between the 2 stations. There was a higher number of coastal taxa in the families Cottidae, Liparidae (snailfishes), and Pleuronectidae at NH-05, whereas there were more offshore taxa in the family Myctophidae (lanternfishes) at NH-10 (Table 1). Shannon-Wiener diversity index values peaked in March at both stations, although the March value for NH-05 was only slightly higher than the surrounding months, whereas at NH-10 it was about twice as high as the next highest month (Fig. 3).

Monthly densities varied by season, year, and location, but generally peaked during the period of 20002004, especially in winter (Fig. 4). Diversities were
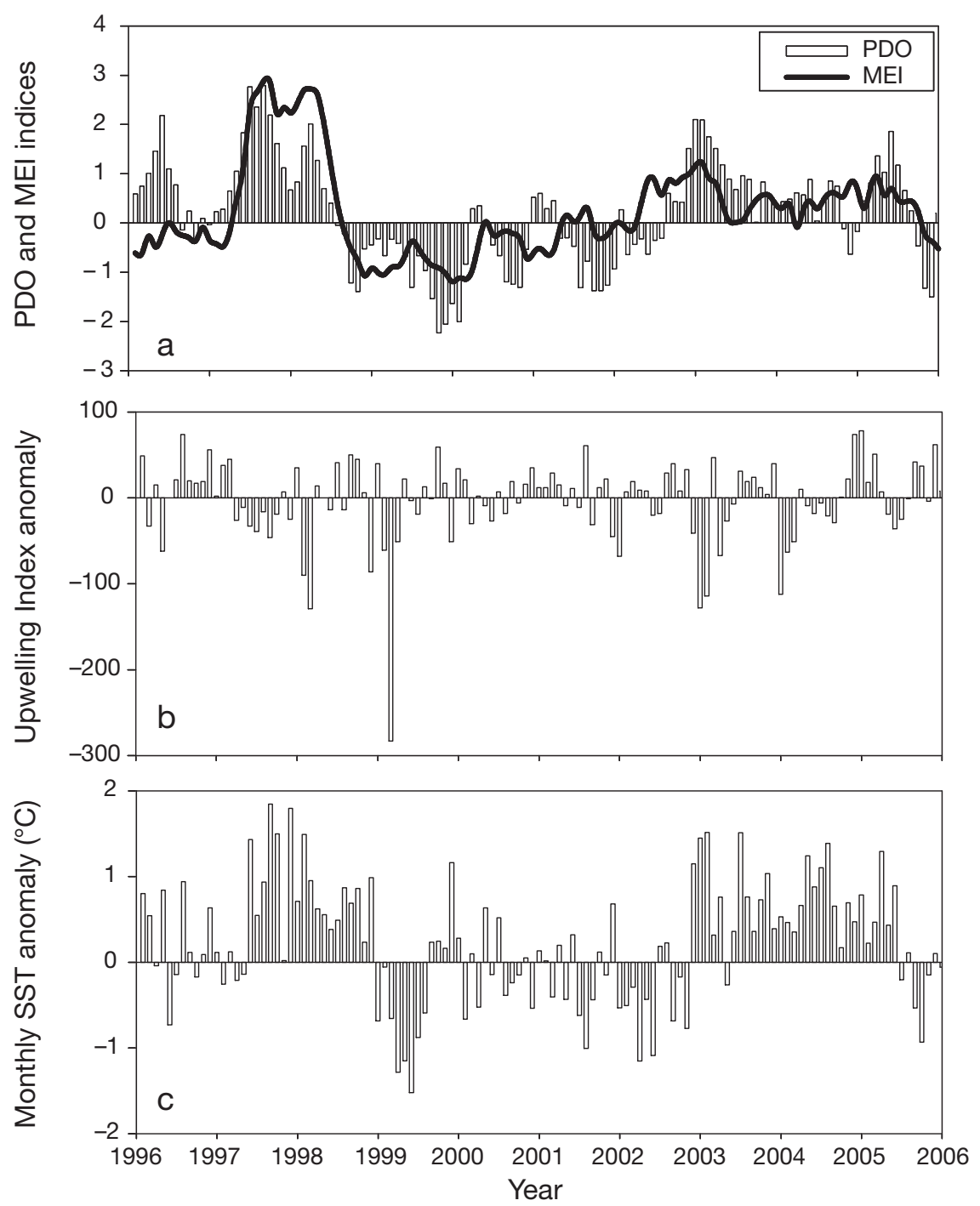

Fig. 2. Time series of environmental variables for the period of our sampling. Shown are the monthly values for the (a) Multivariate ENSO Index (MEI) and Pacific Decadal Oscillation (PDO), (b) Upwelling Index (UI) anomalies for $45^{\circ} \mathrm{N}, 125^{\circ} \mathrm{W}$, and (c) Sea Surface Temperature (SST) anomalies for a $1^{\circ} \times 1^{\circ}$ square off Newport, Oregon. Anomalies based on deviations from the long-term (1970-2005) climatology 


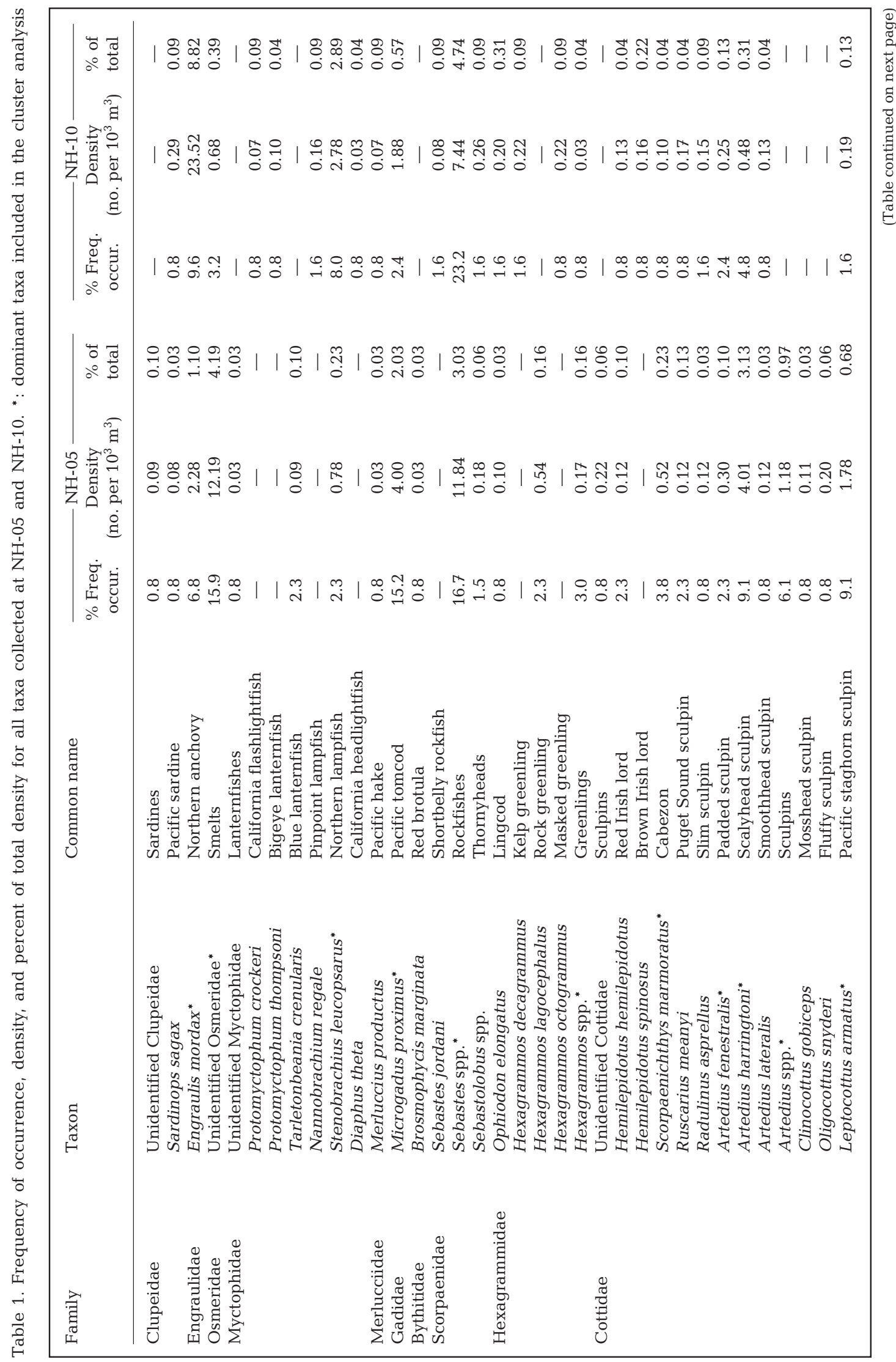




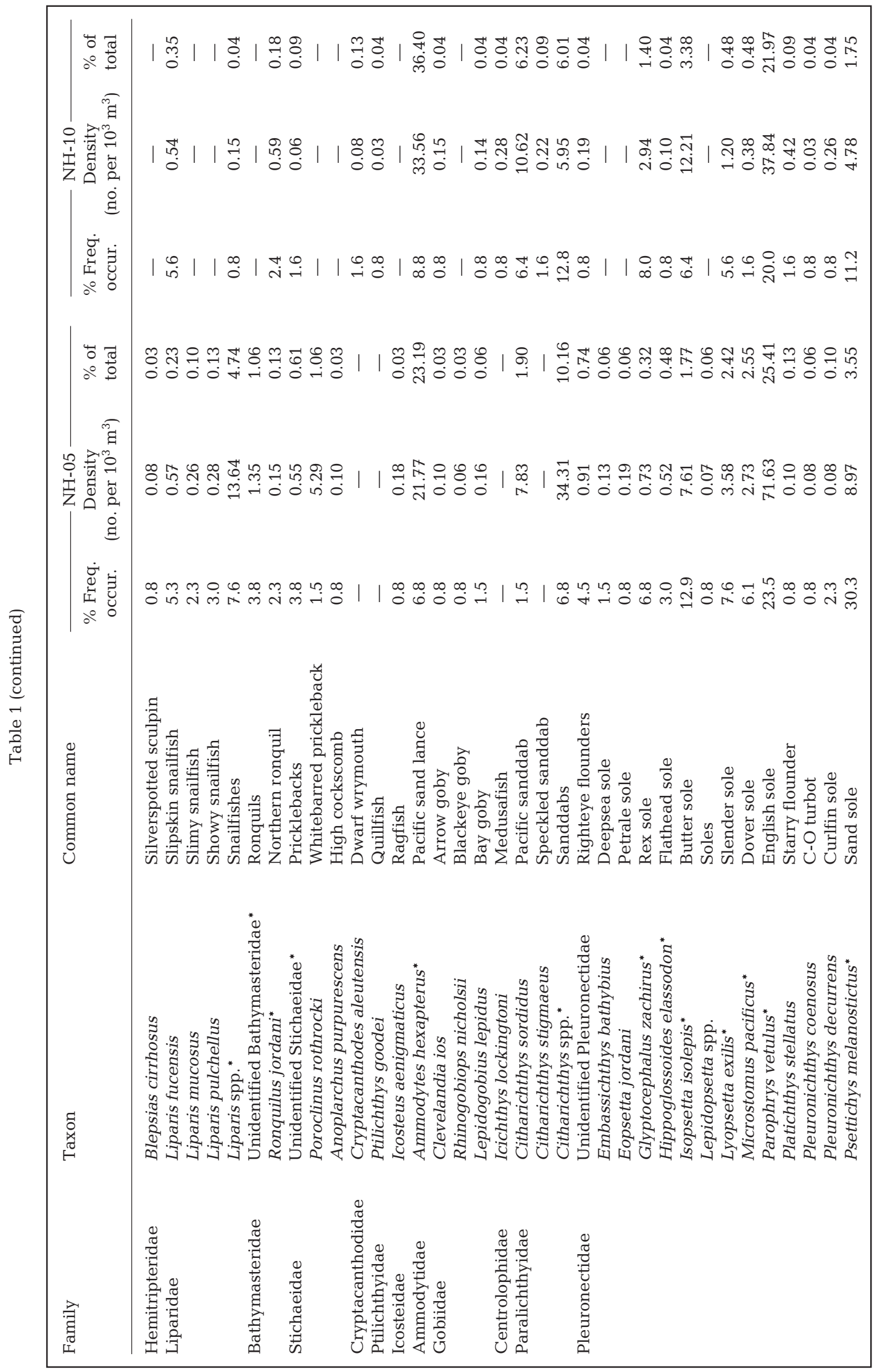



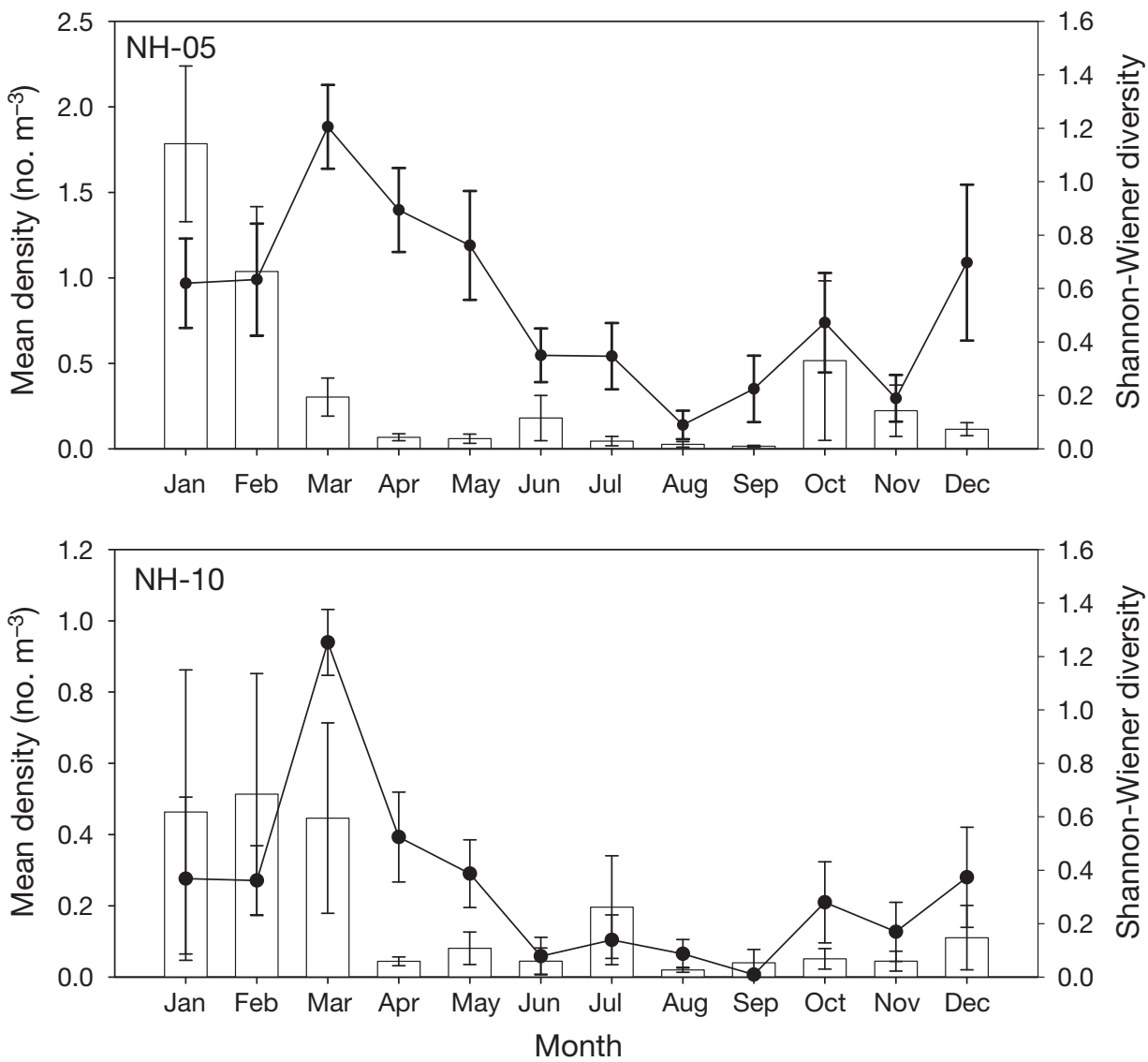

Fig. 3. Mean larval fish density (no. $\mathrm{m}^{-3}$ ) by month for all years combined $(\square)$ and mean Shannon-Wiener diversity $(\bullet)$ for each month from 1996 to 2005 for NH-05 (top) and NH-10 (bottom). Error bars are \pm 1 SE. Note different scales on $y$-axis

very low or equal to 0 (=1 species found) throughout much of the sampling period, and showed a declining trend during the last few years, especially in summer (Fig. 5).

The 10 most abundant taxa, which comprised $87.3 \%$ of the total number of larvae collected at both stations combined (Table 2), showed seasonal variations in density patterns, with Ammodytes hexapterus and Parophrys vetulus dominating in winter and Liparis spp., Citharichthys spp., and Engraulis mordax dominating in summer and fall (Fig. 6). Some taxa were collected over relatively protracted periods of 6 or more months (e.g. P. vetulus, Sebastes spp., Citharichthys spp.), whereas others were collected predominantly in 1 or 2 months (e.g. E. mordax, A. hexapterus, Liparis spp.).

Interannual variations in standardized densities of dominant larval taxa were also related to the PDO. During the cool phase of the PDO (1999-2002) (Fig. 2), the larval fish assemblage was dominated by Ammodytes hexapterus, Citharichthys spp., and Parophrys vetulus, whereas in the second warm phase (20032005), it was dominated by $P$. vetulus, Engraulis mordax, and Sebastes spp. (Table 2). The first warm phase (1997-1998) was greatly affected by the El Niño, and had a somewhat intermediate community but with the same 3 most abundant species as the following cool phase (Table 2). There were significant differences between the community composition in warm vs. cold regimes (MRPP, p < 0.001), but only 6 of the 24 most abundant taxa examined were significantly different enough to be considered indicator taxa (Table 3). MRPP analysis showed no significant differences in community composition among years, but did show significant differences between seasonal and monthly periods (Table 3). Indicator species were found mainly for January and March (month) and winter-spring (season). Despite some minor differences in the dominant species composition between stations, the MRPP results showed no significant differences in the overall community (Table 3), justifying our combining these for the community analyses.

Analysis of the temperatures from NH-05 during each collection (Table 4) revealed that during the PDO cool phase (1999-2002), the mean temperature $\left(10.2^{\circ} \mathrm{C}\right)$ for the early part of the year, when larvae 

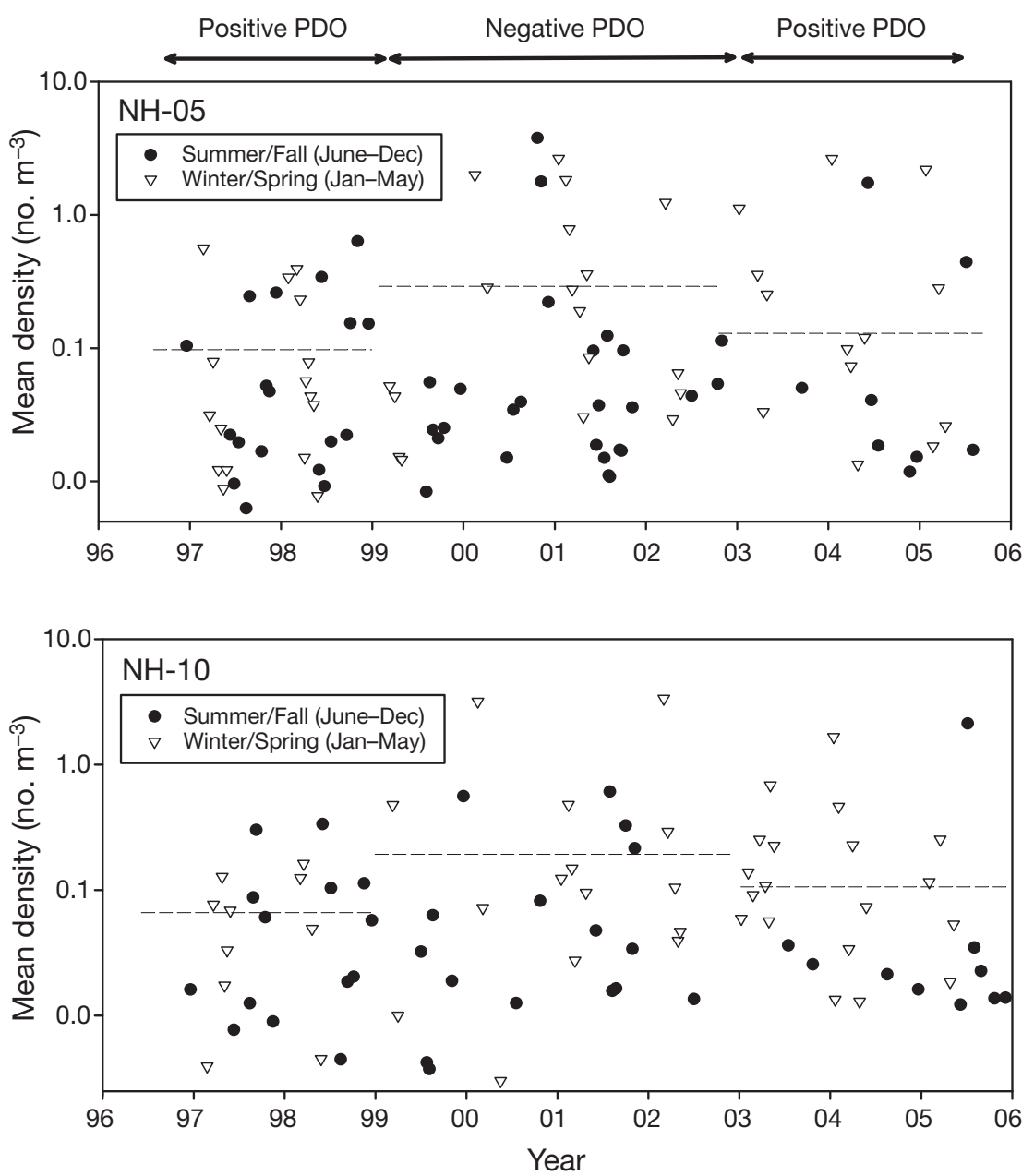

Fig. 4. Mean larval fish density (no. $\mathrm{m}^{-3}$ ) per haul grouped by season. (---): mean values for each of the 3 regime periods for both seasons combined. Note that the $y$-axis is on a log scale

were most abundant (Fig. 3), was significantly lower (ttests, $\mathrm{p}$-value $<0.01$ ) than the early year temperatures for either of the 2 adjacent warm periods (1997-1998 and 2003-2005). However, the latter 2 periods were not significantly different from each other $(p=0.65)$.

Chl a concentrations were not related to patterns of the PDO and ichthyoplankton abundance. Concentrations in winter-spring were low during the first $2 \mathrm{yr}$ of the study, averaging $0.9 \mu \mathrm{g} \mathrm{chl} \mathrm{a} \mathrm{l}^{-1}$ (January-May),

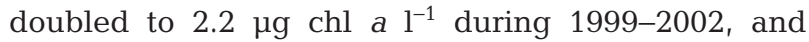
remained high through 2003-2005, averaging $2.3 \mu \mathrm{g}$ chl a $1^{-1}$ (Table 4). Chl a concentrations during the upwelling season (May-September) showed a similar pattern with lower concentrations during the first $2 \mathrm{yr}$ of the study (4.6 $\mathrm{\mu g} \mathrm{chl} \mathrm{a} \mathrm{^{-1 }}$ ), increasing to 6.1 and

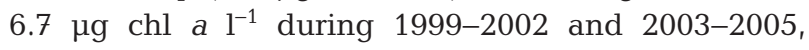
respectively.

In contrast, variations in copepod biomass among the 2 PDO phases were related to variations in ichthyoplankton densities, with copepod biomass low during warm phases and high during the cold phase (Table 4). Biomass from JanuaryMay during the warm period of 1997-1998 was significantly lower than the other 2 time periods. Significant differences between warm and cold phases of the PDO were clearly seen when the biomass anomalies of 'cold-water' and 'warm-water' copepod species are compared (Table 4). Cold-water species had positive anomalies during the cool phase of the PDO (19992002) and when the larval fish assemblage was dominated by cold-water species such as osmerids and sand lance; cold-water species had negative anomalies during the warm phase of the PDO, 1997-1998 and 2003-2005. Warm-water species had low biomass during the negative (cool) phase and high biomass during the positive (warm) phase of the PDO.

\section{Assemblage analyses}

Cluster analyses based on the 24 most abundant taxa by month revealed several different groupings. First, at the highest level, 2 distinct groups fit a well-demarcated seasonal pattern spanning June through December (Fig. 7, upper half) and January through May. Only 3 months (June and July 2004, and June 2005) clustered outside their respective summer-fall (June-December) assemblage (Fig. 7). At a secondary level, 4 groups can be recognized which suggest a change in community structure during the year 2001. Among these 4 clusters, Cluster 1 contained samples from June through December 1996-2001, and Cluster 2, July through November 2001-2005. The break in 2001 appeared to occur between September and October. The other 2 clusters divided January-May into 2 stanzas: Cluster 3, January through March 1997-2001; and Cluster 4, JanuaryJune 2001-2005. Finally, Cluster 1 could be further subdivided into 2 parts, $1 \mathrm{~A}$ and $1 \mathrm{~B}$, with $1 \mathrm{~A}$ being samples from winter and $1 \mathrm{~B}$ being samples from summer.

These groupings corresponded somewhat to the phase of the PDO as well. For the seasonal grouping, $63 \%$ of the months within the winter-spring cluster were associated with a negative PDO, whereas for the summer-fall cluster only $22 \%$ of the months had a negative PDO. When we examine the data in terms of the 4 clusters defined above, we found that the months associated with Cluster 1 (primarily July-August and November-December 1997-2001) had negative PDO 

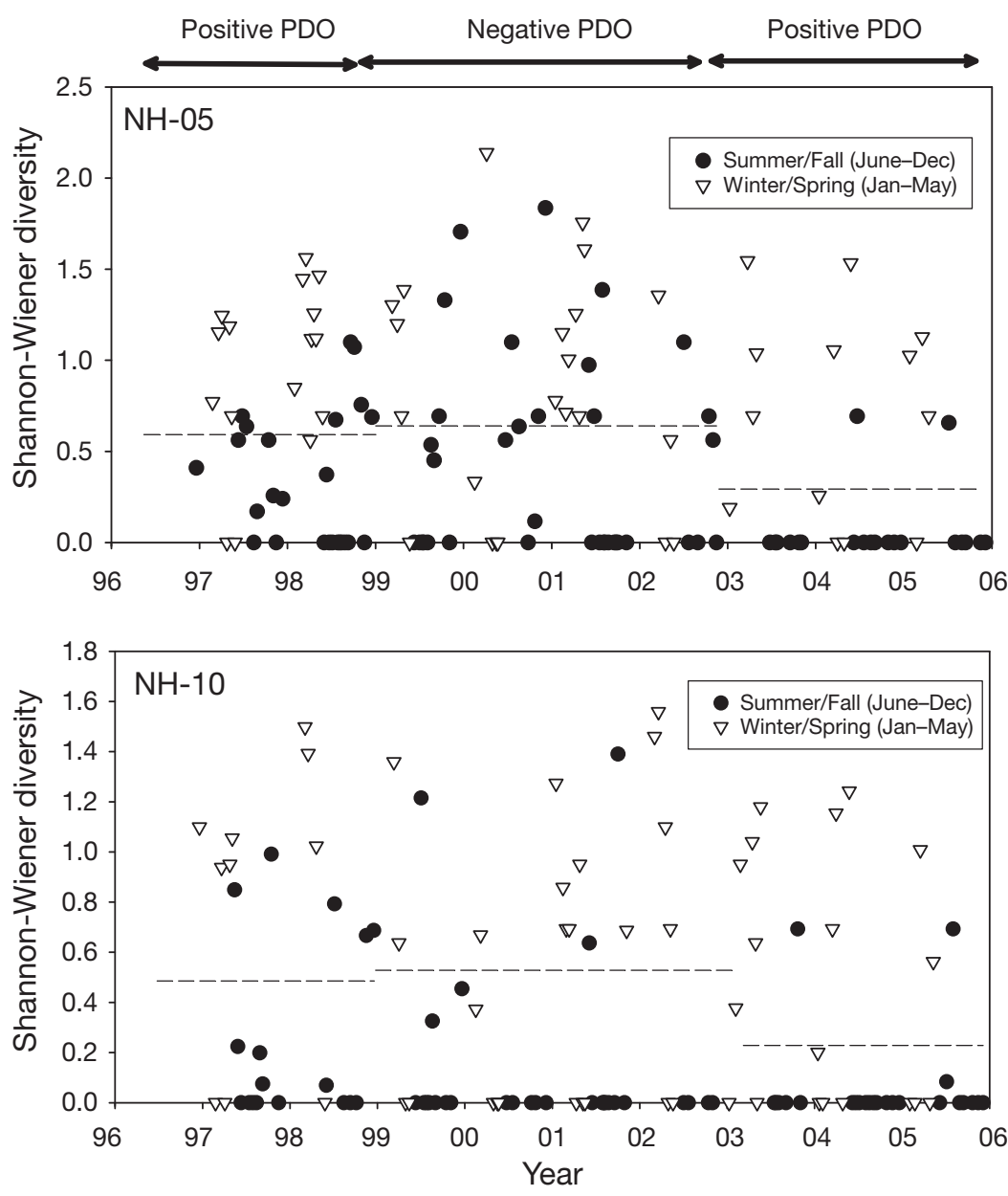

Fig. 5. Shannon-Wiener diversity per haul grouped by season. (---): mean values for each of the 3 regime periods for both seasons combined

the negative PDO signal seemed to be more evident in samples collected from June through December.

We also compared correspondence of ichthyoplankton samples assigned to the 4 clusters with copepod species richness in those same sampling dates, using the data published in Hooff \& Peterson (2006). We found for the samples in Clusters 1 and 3 (months from the years 1996-2001) that anomalously low copepod species richness was associated with ichthyoplankton in $53 \%$ and $68 \%$ of the months, respectively, whereas Clusters 2 and 4 (months from the years 2001-2005) were associated with months with anomalously high copepod species richness (73 and 68\%, respectively).

Cluster analyses by taxon showed assemblages corresponding to known spawning period distributions (Fig. 8). These included a winter-spawning group and large spring-spawning group. The taxa which were classified as most distinct from the others in their occurrence were the summer-spawning Engraulis mordax and the fall-spawning Bathymaster spp. (Fig. 8). Other taxa which were distinct from the main groupings consisted of groupings at higher taxonomic categories (e.g. Osmeridae, Artedius spp., Liparis spp.) that may consist of several unidentifiable species with potentially different spawning times (Fig. 8).

values for $69 \%$ of the dates, Cluster 2 (primarily September-November 2001-2005) had $45 \%$ of the dates with a negative PDO, whereas Clusters 3 and 4 (primarily January-May) had only $26 \%$ and $18 \%$, respectively, of the dates with a negative PDO. Thus
The 2-dimensional NMS ordination of the ichthyoplankton community showed moderate stress (10.34), indicative of some divergence of the 3 regimes along axes 1 and 2 (Fig. 9). Regime 1 samples (1997-1998) were associated with positive values along axis 1 but

Table 2. Numbers and percentages of total catch for the 10 most abundant taxa collected in this study. Also shown are the mean densities (SE) in no. $10^{3} \mathrm{~m}^{-3}$ for the years within each major oceanographic regime period

\begin{tabular}{|c|c|c|c|c|c|}
\hline \multirow[t]{2}{*}{ Species } & \multirow[t]{2}{*}{ Overall total no. } & \multirow[t]{2}{*}{$\%$ of total } & & \multirow{2}{*}{$\begin{array}{l}\text { Densities } \\
\text { 1999-2002 }\end{array}$} & \multirow[b]{2}{*}{$2003-2005$} \\
\hline & & & 1997-1998 & & \\
\hline Ammodytes hexapterus & 1549 & 29.2 & $11.6(10.4)$ & $73.6(58.5)$ & $3.8(2.3)$ \\
\hline Parophrys vetulus & 1289 & 24.3 & $27.1(11.3)$ & $85.8(34.6)$ & $73.8(40.9)$ \\
\hline Citharichthys spp. & 655 & 12.4 & $26.2(15.2)$ & $49.6(31.0)$ & $20.3(11.6)$ \\
\hline Engraulis mordax & 235 & 4.4 & $1.8(0.8)$ & $4.1(3.7)$ & $35.7(34.2)$ \\
\hline Sebastes spp. & 204 & 3.8 & $3.9(1.3)$ & $5.7(2.3)$ & $39.6(34.0)$ \\
\hline Liparis spp. & 170 & 3.2 & $1.4(0.7)$ & $1.3(0.4)$ & 13.9 (13.3) \\
\hline Psettichthys melanostictus & 150 & 2.8 & $2.8(1.1)$ & $8.6(3.4)$ & $6.6(2.2)$ \\
\hline Osmeridae & 139 & 2.6 & $4.1(3.3)$ & $16.1(13.1)$ & $1.3(0.8)$ \\
\hline Isopsetta isolepis & 132 & 2.5 & $1.0(0.4)$ & $22.5(21.1)$ & $3.3(1.6)$ \\
\hline Artedius harringtoni & 104 & 2.0 & $4.8(4.5)$ & $1.6(0.6)$ & $0.7(0.4)$ \\
\hline Total & 4627 & 87.3 & & & \\
\hline
\end{tabular}



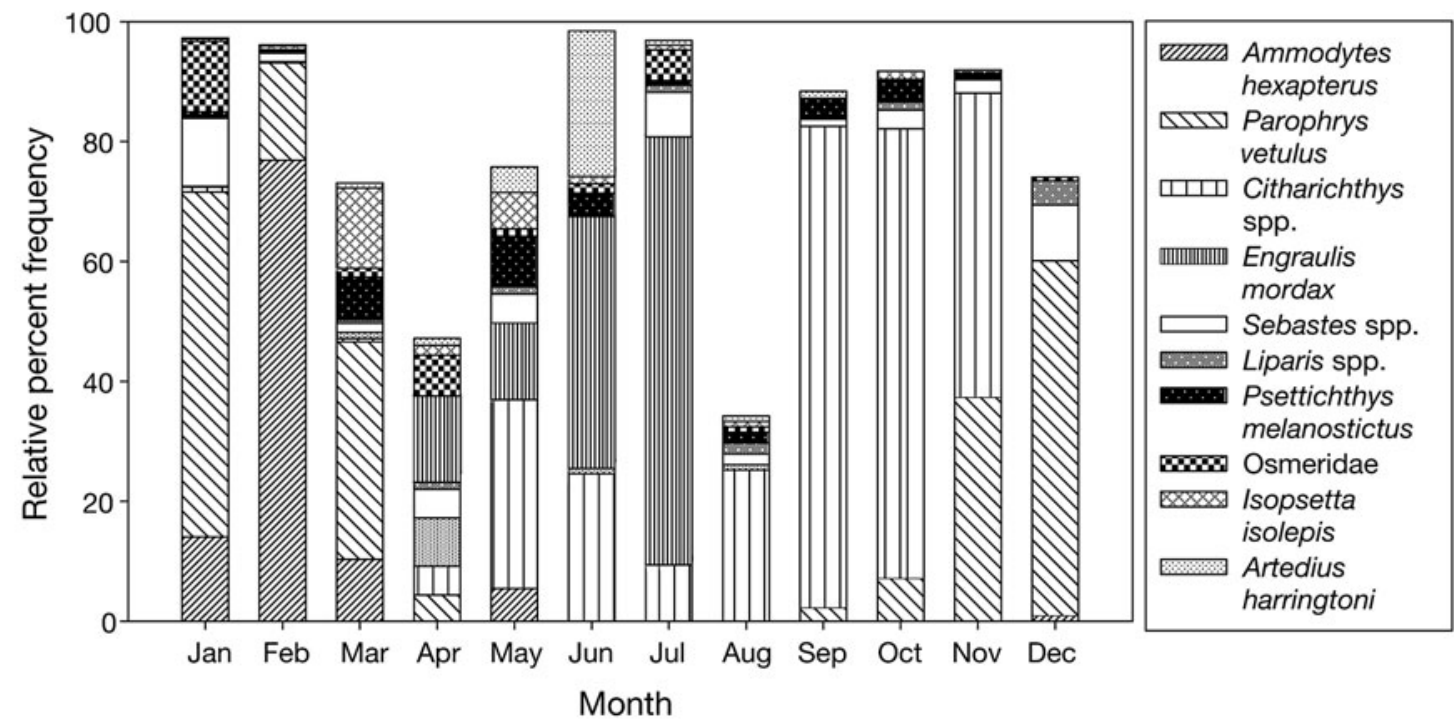

Fig. 6. Monthly catch summaries of the 10 most abundant taxa expressed as percentages of the total monthly catches

Table 3. Results of the Multi-Response Permutation Procedure (MRPP) and indicator species analysis for station regime, annual, seasonal, and monthly differences in composition of the dominant (top 24) ichthyoplankton taxa. Significant indicator species are listed with the regime, season, or month with which each species is associated in parentheses. See Table 1 for full species' name

\begin{tabular}{|c|c|c|c|}
\hline Factor & MRPP A-statistic & $\mathrm{p}$-value & Significant indicator species $(\mathrm{p}<0.05)$ \\
\hline Station & 0.0012 & 0.312 & None significant \\
\hline Regime & 0.1170 & $<0.001$ & $\begin{array}{l}\text { E. mordax, } P \text {. vetulus, and Sebastes spp. (warm); } \\
\text { A. hexapterus, Citharichthys spp., and Osmeridae (cold) }\end{array}$ \\
\hline Year & 0.0004 & 0.449 & None significant \\
\hline Season & 0.0095 & $<0.001$ & $\begin{array}{l}\text { G. zachirus, M. pacificus, I. isolepis, P. vetulus, } \\
\text { P. melanostictus, R. jordani, S. marmoratus, Sebastes spp., } \\
\text { S. leucopsarus, Osmeridae, } \\
\text { and Stichaeidae (winter-spring); E. mordax (summer-fall) }\end{array}$ \\
\hline Month & 0.0462 & $<0.001$ & $\begin{array}{l}\text { Osmeridae, P. vetulus, and Sebastes spp. (January); } \\
\text { G. zachirus and S. leucopsarus (March); E. mordax (July) }\end{array}$ \\
\hline
\end{tabular}

Table 4. Mean values (SE) of physical and biological variables summarized for the 3 PDO phases. Log N: $\log _{e}$ of northern (cold water); $\log \mathrm{S}$ : $\log _{\mathrm{e}}$ of southern (warm water) copepod species (see text)

\begin{tabular}{|c|c|c|c|}
\hline PDO phase & $\begin{array}{c}\text { 1997-1998 } \\
\text { Warm }\end{array}$ & $\begin{array}{c}1999-2002 \\
\text { Cold }\end{array}$ & $\begin{array}{c}\text { 2003-2005 } \\
\text { Warm }\end{array}$ \\
\hline Sea surface temperature $\left({ }^{\circ} \mathrm{C}\right)$ January-May & $11.8(0.3)$ & $10.2(0.2)$ & $11.4(0.2)$ \\
\hline Chlorophyll ( $\left.\mu g \mathrm{l}^{-1}\right)$ January-May & $0.9(0.2)$ & $2.2(0.4)$ & $2.3(0.5)$ \\
\hline Chlorophyll $\left(\mu \mathrm{g} \mathrm{l}^{-1}\right)$ May-September & $4.6(0.8)$ & $6.1(0.8)$ & $6.7(1.2)$ \\
\hline Copepod biomass $\left(\mathrm{mg} \mathrm{C} \mathrm{m}^{-3}\right.$ ) January-May & $7.5(1.6)$ & $12.6(1.4)$ & $11.0(1.7)$ \\
\hline Copepod biomass $\left(\mathrm{mg} \mathrm{C} \mathrm{m}^{-3}\right.$ ) May-September & $5.6(0.9)$ & $15.4(1.5)$ & $9.9(1.4)$ \\
\hline Log N copepod biomass anomaly $\left(\mathrm{mg} \mathrm{C} \mathrm{m}^{-3}\right)$ & $-0.41(0.09)$ & $0.28(0.04)$ & $-0.26(0.08)$ \\
\hline Log $\mathrm{S}$ copepod biomass anomaly $\left(\mathrm{mg} \mathrm{C} \mathrm{m}^{-3}\right)$ & $0.69(0.14)$ & $-0.49(0.08)$ & $0.68(0.14)$ \\
\hline $\mathrm{NH}-05$ larval density (no. $10^{3} \mathrm{~m}^{-3}$ ) & $97.9(24.9)$ & $299.9(93.2)$ & $120.3(59.6)$ \\
\hline NH-10 larval density (no. $10^{3} \mathrm{~m}^{-3}$ ) & $67.3(16.6)$ & $191.3(82.3)$ & $110.6(42.3)$ \\
\hline NH-05 larval diversity & $0.61(0.09)$ & $0.64(0.08)$ & $0.29(0.08)$ \\
\hline NH-10 larval diversity & $0.48(0.11)$ & $0.52(0.08)$ & $0.22(0.09)$ \\
\hline
\end{tabular}


Information remaining (\%)

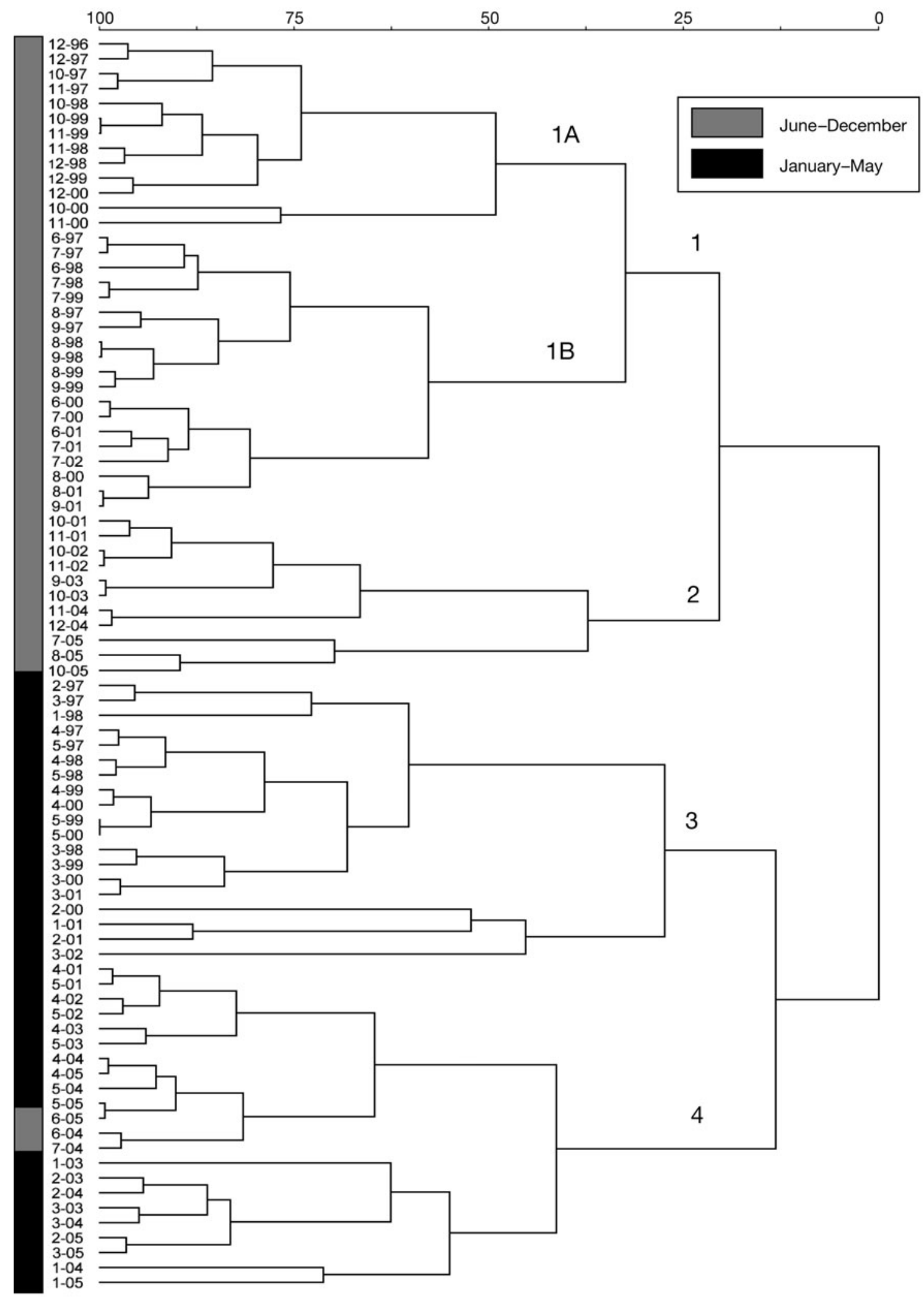

Fig. 7. Cluster analysis of the catches for both stations combined summed by each sampling month. Dates are grouped by bars on the left corresponding to summer-fall (June-December) and winter-spring (January-May) time periods 


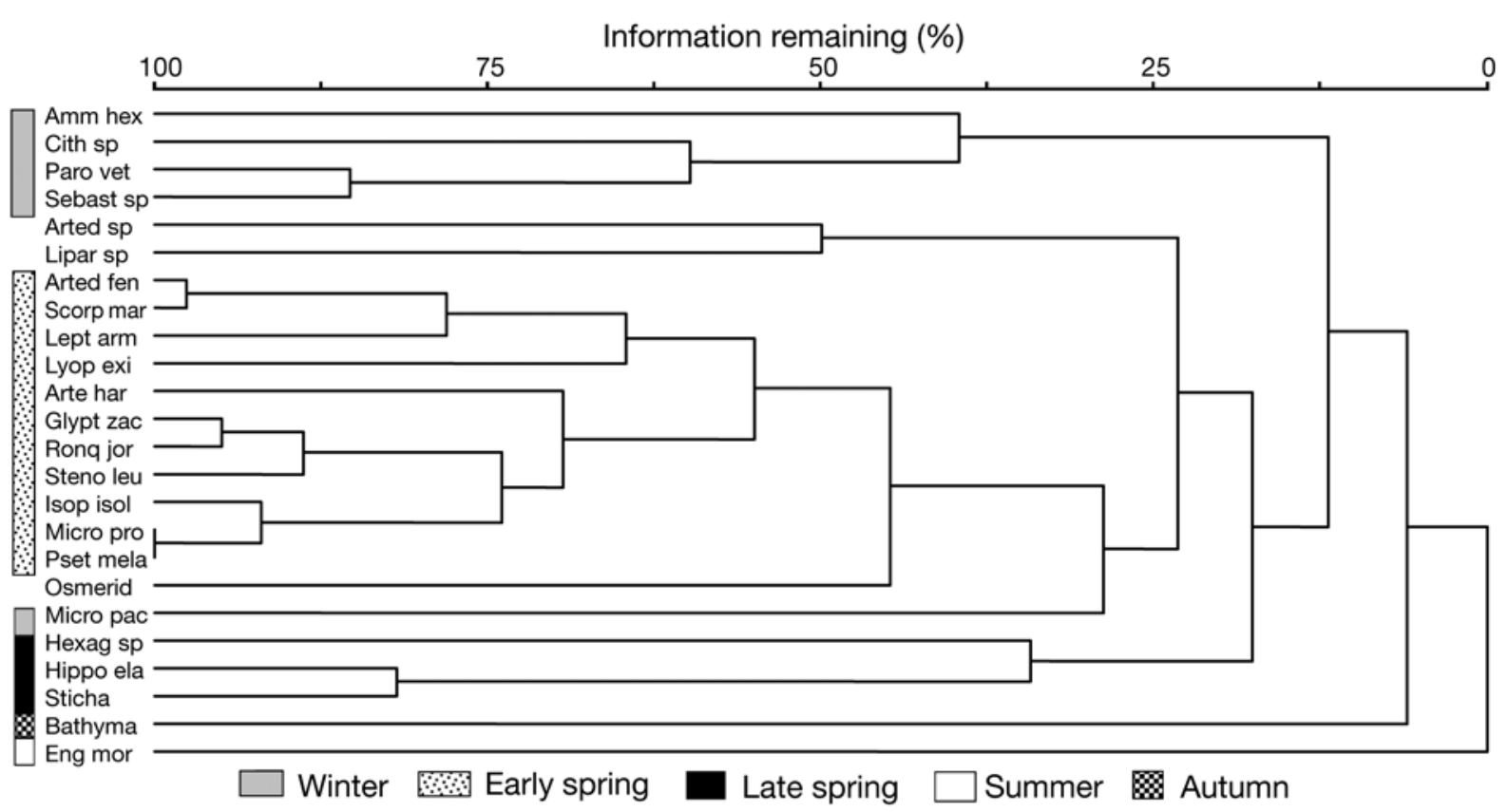

Fig. 8. Cluster analysis by taxa for both stations combined summed by each sampling month. Taxa are grouped by bars on the left corresponding to known spawning periods. Those taxa without defined spawning periods represent multispecies groupings that may have variable spawning times

negative values on axis 2 , and were characterized by a group of warm-water species, most notably Microstomus pacificus and Hexagrammos spp. In contrast, Regime 2 collections were on the opposing quadrant, and were characterized by cold-water taxa (Ammodytes hexapterus, Isopsetta isolepis, Citharichthys spp., and Osmerids). Regime 3 collections occurred in the center or the lower half of the ordination, but in a different orientation compared to the other warm period, Regime 1 (Fig. 9). Dominant taxa associated with this grouping were Engraulis mordax, Parophrys vetulus, and Sebastes spp. the same 3 species found to be indicative of warm ocean conditions in the MRPP analysis (Table 3).

The vectors indicating the effects of the variables showed similar strength and direction for MEI, SST, and PDO indicating that positive values of all 3 of these indices were associated with warm temperatures (Fig. 9). MEI showed a higher correlation with axis 1 $(r=0.512)$ compared with either PDO $(r=0.357)$ or SST ( $r=0.359)$, whereas PDO had the highest correlation with axis 2 ( $\mathrm{r}=-0.513)$. Upwelling (UI) showed an inverse relationship to the other variables as expected, but had relatively little correlation with the axes ( $\mathrm{r}=$ -0.011 and 0.166 with axes 1 and 2, respectively).

\section{DISCUSSION}

The present study represents the longest time series of ichthyoplankton sampled from one location in the northern California Current, and spanned a period of dynamic physical and biological change in the northern California Current. We found some minor differences between the 2 stations located just $9 \mathrm{~km}$ apart, mainly due to the reduced concentrations of coastal taxa and increased concentrations of more oceanic taxa at the station further offshore, but these differences were not found to be significant in terms of density or overall species composition. Our results confirm previous findings that suggest many fish species in the Pacific Northwest upwelling region (Vancouver Island to Cape Blanco, Oregon) spawn in winter, when offshore transport is minimal (Parrish et al. 1981). Richardson \& Pearcy (1977) found high larval fish concentrations in their coastal (2 to $28 \mathrm{~km}$ offshore) assemblage in May through July, although their overall abundances were dominated (>50\%) by smelts, a group that spawn demersally, close to shore, and have a short pelagic dispersal stage, and are thus less subject to offshore transport (Shanks \& Eckert 2005).

Assemblage analysis of our dominant taxa revealed a pronounced seasonal pattern in community composition with winter-spring (January-May) and summerfall (June-December) groupings clearly delineated (Fig. 7). Shenker (1988) found a dramatic change in ichthyoneuston composition between spring and early summer from sampling along the NH line in 1984. This change was brought about by the onset of strong upwelling in early June. In our analysis, only 3 months in early summer 2004 and 2005 did not fall into their appropriate periods. Oceanographic conditions were quite unusual during early summer in both of these 
years due to late upwelling and warmer than normal conditions (Barth et al. 2007), and many density and distributional anomalies of zooplankton and nekton populations, such as increased occurrences of offshore or southern species (Brodeur et al. 2006, Mackas et al. 2006), were recorded during these years.

The January-May period exhibited high diversity and density of larval fish taxa, and 11 of the 24 dominant taxa were identified as indicator species for this time period (Table 3). These include several species that have relatively brief periods of occurrence (Ammodytes hexapterus and Isopsetta isolepis) as well as some that have more extended occurrences over several months (Sebastes spp., Citharichthys spp., and Parophrys vetulus). The protracted collection periods for Sebastes spp. found in our study can possibly be explained by the fact that up to 45 species of rockfish occur off the coast of Oregon (Love et al. 2002). The only rockfish in our study that was identified to the species level was $S$. jordani, and it is likely that the remainder of unidentified Sebastes spp. represents a diversity of species with different parturition times. Rockfishes are ovoviviparous and, off Oregon, females have been shown to contain eyed larvae during all months of the year except October, with peak parturition from January through July (Love et al. 2002). Preflexion Sebastes larvae of the size collected in our study cannot be separated by meristic or pigmentation patterns and can be reliably differentiated only by genetic analysis (Gray et al. 2006).

Richardson \& Pearcy (1977) found that English sole Parophrys vetulus spawned primarily from January through March, with most of the larvae settling out to demersal habitats by July, which could explain the protracted occurrences of larval English sole in this study. Laroche \& Richardson (1979) estimated that the duration of pelagic life for this species is on the order of 18 to 22 wk. Sanddabs (Citharichthys stigmaeus and C. sordidus) are known to have extended spawning periods as well. Ureña (1989) found that $C$. sordidus spawned late summer through late spring, and C. stigmaeus spawned early spring through late fall. Much like Sebastes spp., Citharichthys spp. larvae are difficult to identify to species at early stages.

The summer-fall larval fish community is comparatively much less diverse in this region, with only northern anchovy Engraulis mordax found to be indicative of this time period and more specifically July. This species generally spawns within the stratified and relatively productive Columbia River plume (Richardson 1973) and has shown to be an indicator species during summer in the plume (Parnel et al. 2008). This is a region of relatively weak geostrophic flow outside the region of maximum upwelling (Parrish et al. 1981), and thus is not as susceptible to offshore transport during the summer. However, in warm years such as might occur during El Niño Southern Oscillation (ENSO) conditions (Brodeur et al. 1985, Doyle 1995) or years of low upwelling (e.g. 2005; Brodeur et al. 2006), E. mordax larvae can be found earlier in the season and occurring over a broader geographic area.

Our results were different from other larval fish studies conducted off Newport over the last few decades in several notable ways. Pacific sardine Sardinops sagax has been known to spawn off Oregon only since the mid-1990s, having expanded its range into the northern California Current shortly before this study following an absence of over 40 yr (Emmett et al. 2005). Also, Pacific hake Merluccius productus larvae were recorded in low numbers at both stations during this

NMS by regime

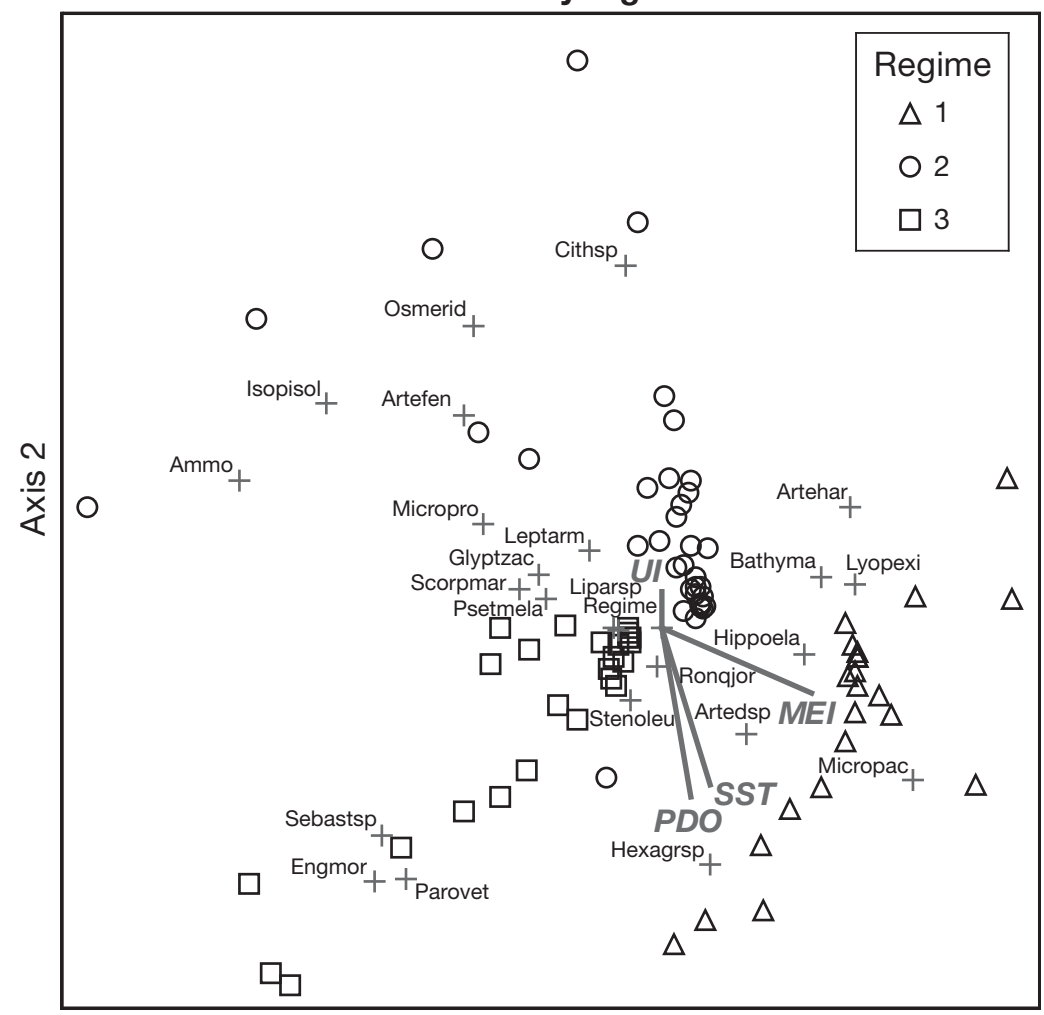

Axis 1

Fig. 9. Non-metric multidimensional scaling (NMS) analysis of the 84 cruise months showing the relationship for the first 2 axes. Shown are the individual months (open symbols) categorized by the 3 regimes, the dominant taxa (+ with names), and the vectors showing the direction and relative strength of the 4 environmental variables examined (grey lines with italic labels) 
period. Although Pacific hake larvae were reported off southern Oregon during the ENSO years of 1983 and 1998, they are extremely rare north of the southern California Current (Doyle 1995). However, Pacific hake have spawned in the northern California Current each year since at least 2004, and all these observations occurred during non-ENSO conditions (Phillips et al. 2007). Although neither of these species was common in our samples, due in part to the nearshore location of sampling, their occurrence alone reflects a dramatic change in spawning behavior since the previous periods of intensive ichthyoplankton sampling (e.g. Richardson 1973, Richardson \& Pearcy 1977, Brodeur et al. 1985, Doyle et al. 1993).

The density and composition of the larval fish community changed dramatically starting in winter 19992000, with overall densities of several species being higher than observed in the preceding years. Smelts in particular became abundant during the 4 negative (cool) PDO years (1999-2002). This is in agreement with Richardson \& Pearcy (1977), who found a high abundance of smelts in the early 1970s, also a period of negative PDO. Smelts were much less abundant during the relatively warm years of the 1980s (Brodeur et al. 1985, Doyle et al. 1993). With the change in sign of the PDO in November 2002, we saw a decrease in smelt larvae but increased numbers of larvae of offshore species (e.g. northern anchovy and rockfishes). Diversities and densities at the 2 stations peaked between 1999 and 2002 and have been substantially lower since 2003 (Table 4, Figs. 3 \& 4), perhaps due to the warm ocean conditions and low productivity in recent years (Brodeur et al. 2006). In the nearshore region off Oregon, Barth et al. (2007) suggested that very low chlorophyll concentrations in 2005 contributed to depressed recruitment of mussels and barnacles off Oregon. A similar situation could be occurring in the larval fish population, and perhaps was manifested in low diversity and concentrations that summer.

The cluster analysis revealed not only seasonal differences, but differences among years. For example, most of the dates in Clusters 1 and 3 were from 1997-2001, whereas most of the dates in Clusters 2 and 4 were samples collected in 2001-2005. When we compared the copepod species richness in those same samples, we found that Cluster 1 and 3 had negative species richness anomalies (average of $59 \%$ of the samples), whereas $70 \%$ of the samples in Clusters 2 and 4 had positive copepod species richness anomalies. This suggests that there was some fundamental change in ecosystem structure during our study: the larval fish community was associated with low copepod species richness in 1997-2001, but beginning in 2001, fish larvae came to be associated with high copepod species richness. We have no ready explanation for this but clearly more study is needed.

The ultimate meaning of the ordination analysis is that the ichthyoplankton community is directly related to the 3 phase change points of the PDO (1997-1998 warm phase, 1999-2002 cold phase, and 2003-2005 warm phase). Hooff \& Peterson (2006) showed that copepod species richness was high during the warm years of 1996-1998, low during 1999-2002, followed by increased richness in 2003-2005, a pattern clearly related to and significantly correlated with the PDO. Moreover, Hooff \& Peterson (2006) suggested that years with high species richness were due to either northward or onshore transport (or both) of the more diverse southern or offshore assemblage of copepods, especially in winter. Since the larval fish community structure was divided more on strict seasonal lines (January-May and June-December) due to seasonal spawning strategies, whereas the copepod community divides along seasonal changes in transport within the northern California Current, the 2 communities may be responding to environmental variability in fundamentally different ways. In addition, because of the effect of a strong El Niño in the first regime, we found that the larval fish assemblage found in this regime was somewhat different than that of the third regime despite both being warm phases. Clearly, a more detailed analysis of the environmental conditions and possible relationships between copepod and larval fish abundances and diversity is warranted, and is presently underway using a longer time series of historical ichthyoplankton data starting in the 1970s and a broader suite of environmental data (T. D. Auth et al. unpubl. data).

Although our time series of larvae spans only 2 distinct oceanographic shifts, our results show that cool PDO years were dominated by nearshore species with northern or nearshore affinities such as smelts, sanddabs, and sand lance, whereas warm years were dominated by offshore or more southern species such as anchovies, English sole, and rockfishes. Moser et al. (1987) found fluctuations between 'northern' and 'southern' communities of larvae based on 7 yr (19541960) of data. Their collections were made during the California Cooperative Oceanic Fisheries Investigations (CalCOFI) program, and they were able to relate changes in larval fish communities to environmental changes during this period.

In addition to the abiotic environment, other factors could be influencing changes in abundance patterns of larval fishes in our region that we were not able to address in this study. Changes in the migration behavior of adults (Emmett et al. 2005, Phillips et al. 2007) or fishery-related depression of the adult spawning 
population (Hsieh et al. 2006) may affect the local reproductive output for many species. Pronounced changes in small forage fish (smelts, anchovies, sardines) and predator fish (hake and mackerel) abundances related to shifts in temperatures and food availability have been documented for the northern California Current during this time period (Brodeur et al. 2005, 2006, Emmett et al. 2006). Interannual variations in the timing of the spring bloom (Henson \& Thomas 2007) and subsequent microzooplankton production may be critical to the availability of food to first-feeding and later-stage larvae (Bollens et al. 1992, Haldorson et al. 1993, Platt et al. 2003). Also, the occurrence and relative abundance of planktivorous predators in the spawning area can greatly affect egg and larval survival (Bailey \& Houde 1989, Cowan \& Houde 1993).

The coincidence we observed in the timing between large-scale shifts in climate and larval fish abundance and composition suggests that regional environmental conditions can have substantial direct impacts on larval fish abundance and possibly survival. Larval fishes in turn may serve as key indicators for changes in the marine ecosystem because of their relatively quick response time compared to adult populations (Boeing \& Duffy-Anderson 2008). Based upon our analyses, we have identified a small subset of fish species whose larvae can be monitored as indicators of warm and cold phases in the northeast Pacific Ocean.

Acknowledgements. We thank L. Feinberg, T. Shaw, J. Keister, and $M$. Vance for assistance in sampling. We also thank R. Hooff, S. Remples, and J. Colbert for assistance in data analysis, and E. Bjorkstedt, E. Casillas, M. Doyle, and several anonymous reviewers for comments on earlier versions of this manuscript. This research was funded by the Fisheries and the Environment (FATE) initiative and the U.S. Global Ocean Ecosystems Dynamics (GLOBEC) Northeast Pacific (NEP) Program (contribution 595).

\section{LITERATURE CITED}

Auth TD, Brodeur RD (2006) Distribution and community structure of ichthyoplankton off the coast of Oregon, USA, in 2000 and 2002. Mar Ecol Prog Ser 319:199-213

Bailey KM, Houde ED (1989) Predation on eggs and larvae of marine fishes and the recruitment problem. Adv Mar Biol 25:1-83

Barth JA, Menge BA, Lubchenco J, Chan F and others (2007) Delayed upwelling alters nearshore coastal ocean ecosystems in the northern California Current. Proc Natl Acad Sci USA 104:3719-3724

Boehlert GW, Gadomki GM, Mundy BC (1985) Vertical distribution of ichthyoplankton off the Oregon Coast in spring and summer months. Fish Bull 83:611-621

Boeing WJ, Duffy-Anderson JT (2008) Ichthyoplankton dynamics and biodiversity in the Gulf of Alaska: responses to environmental change. Ecol Indic 8:292-302
Bollens SM, Frost BW, Schwaninger HR, Davis CS, Way KL, Landsteiner MC (1992) Seasonal plankton cycles in a temperate fjord, and comments on the match-mismatch hypothesis. J Plankton Res 14:1279-1305

Brodeur RD, Gadomski DM, Pearcy WG, Batchelder HP, Miller CB (1985) Abundance and distribution of ichthyoplankton in the upwelling zone off Oregon during anomalous El Niño conditions. Estuar Coast Shelf Sci 21: 365-378

> Brodeur RD, Fisher JP, Morgan CA, Emmett RL, Casillas E (2005) Species composition and community structure of pelagic nekton off Oregon and Washington under variable oceanographic conditions. Mar Ecol Prog Ser 298:41-57

Brodeur RD, Ralston S, Emmett RL, Trudel M, Auth TD, Phillips AJ (2006) Anomalous pelagic nekton abundance, distribution, and apparent recruitment in the northern California Current in 2004 and 2005. Geophys Res Lett 33:L22S08, doi:10.1029/2006GL026614

> Cowan JH Jr, Houde ED (1993) Relative predation potentials of schyphomedusae, ctenophores and planktivorous fish on ichthyoplankton in Chesapeake Bay. Mar Ecol Prog Ser 95:55-65

Cushing DH (1982) Climate and fisheries. Academic Press, New York

Doyle MJ (1995) The El Niño of 1983 as reflected in the ichthyoplankton off Washington, Oregon, and northern California. Can Spec Pub Fish Aquat Sci 121:161-180

Doyle MJ, Morse WW, Kendall AW Jr (1993) A comparison of larval fish assemblages in the temperate zone of the northeast Pacific and northwest Atlantic oceans. Bull Mar Sci 53:588-644

Doyle MJ, Mier KL, Busby MS, Brodeur RD (2002) Regional variations in springtime ichthyoplankton assemblages in the Northeast Pacific Ocean. Prog Oceanogr 53:247-281

Dufrene M, Legendre P (1997) Species assemblages and indicator species: the need for a flexible asymmetrical approach. Ecol Monogr 67:345-366

Emmett RL, Brodeur RD, Miller TW, Pool SS, Krutzikowsky GK, Bentley PJ, McCrae J (2005) Pacific sardine (Sardinops sagax) abundance, distribution, and ecological relationships in the Pacific Northwest. Calif Coop Ocean Fish Invest Rep 46:122-143

Emmett RL, Krutzikowsky GK, Bentley P (2006) Abundance and distribution of pelagic piscivorous fishes in the Columbia River plume during spring/early summer 19982003: relationship to oceanographic conditions, forage fishes, and juvenile salmonids. Prog Oceanogr 68:1-26

> Fogarty MJ (1993) Recruitment in randomly varying environments. ICES J Mar Sci 50:247-260

Gray AK, Kendall AW Jr, Wing BL, Carls MG, Heifitz J, Li Z, Gharrett AJ (2006) Identification and first documentation of larval rockfishes in Southeast Alaskan waters was possible using mitochondrial markers but not with pigmentation patterns. Trans Am Fish Soc 135:1-11

Haldorson L, Pritchett M, Sterritt D, Watts J (1993) Abundance patterns of marine fish larvae during spring in a southeastern Alaskan bay. Fish Bull 91:36-44

> Henson SA, Thomas AC (2007) Interannual variability in timing of bloom initiation in the California Current system. J Geophys Res 112:C08007, doi:10.1029/2006JC003960

Hooff RC, Peterson WT (2006) Copepod biodiversity as an indicator of changes in ocean and climate conditions of the northern California Current ecosystem. Limnol Oceanogr 51:2607-2620

Houde ED (1997) Patterns and consequences of selective processes in teleost early life histories. In: Chambers RC, Trippel EA (eds) Early life history and recruitment in fish populations. Chapman \& Hall, London, p 172-196 
Hsieh C, Reiss C, Watson W, Allen MJ and others (2005) A comparison of long-term trends and variability in populations of larvae of exploited and unexploited fishes in the Southern California region: a community approach. Prog Oceanogr 67:160-185

Hsieh C, Reiss C, Hunter JR, Beddington JR, May RM, Sugihara G (2006) Fishing elevates variability in the abundance of exploited species. Nature 443:859-862

Hunter JR, Lo NCH (1993) Ichthyoplankton methods for estimating fish biomass: introduction and terminology. Bull Mar Sci 53:723-727

Laroche JL, Richardson SL (1979) Winter-spring abundance of larval English sole, Parophrys vetulus, between the Columbia River and Cape Blanco, Oregon during 1972-1975 with notes on occurrences of three other pleuronectids. Estuar Coast Mar Sci 8:455-476

Lasker R (1985) An egg production method for estimating spawning biomass of pelagic fish: application to the northern anchovy, Engraulis mordax. NOAA Tech Rep NMFS 36

Love MS, Yoklavich M, Thorsteinson L (2002) The rockfishes of the northeast Pacific. University of California Press, Berkeley, CA

Mackas DL, Peterson WT, Ohman MD, Lavaniegos BE (2006) Zooplankton anomalies in the northern California Current system before and during the warm ocean conditions of 2005. Geophys Res Lett 33:L22S07

McCune B, Grace JB (2002) Analysis of ecological communities. MjM Software Design, Gleneden Beach, OR

McCune B, Mefford MJ (1999) PC-ORD, Multivariate analysis of ecological data, users guide. MjM Software Design, Gleneden Beach, OR

McGinn NA (ed) (2002) Fisheries in a changing climate. Am Fish Soc Symp 32

Moser HG, Smith PE, Eber LE (1987) Larval fish assemblages in the California Current region, 1954-1960, a period of dynamic environmental change. CCOFI Rep 28:97-127

Mundy BC (1984) Yearly variation in the abundance and distribution of fish larvae in the coastal upwelling zone off Yaquina Head, OR, from June 1969-August 1972. MSc thesis, Oregon State University, Corvallis, OR

Parnel MM, Emmett RL, Brodeur RD (2008) Ichthyoplankton community in the Columbia River plume off Oregon:

Editorial responsibility: Jon Hare, Narragansett, Rhode Island, USA effects of fluctuating oceanographic conditions. Fish Bull 106:161-173

Parrish RH, Nelson CS, Bakun A (1981) Transport mechanisms and reproductive success of fishes in the California Current. Biol Oceanogr 1:175-203

Peterson WT, Keister JE (2003) Interannual variability in copepod community composition at a coastal station in the northern California Current: a multivariate approach. Deep-Sea Res 50:2499-2517

Peterson WT, Schwing FB (2003) A new climate regime in northeast Pacific ecosystems. Geophys Res Lett 30:1896, doi:10.1029/2003GL017528

Phillips AJ, Ralston S, Brodeur RD, Auth TD, Johnson C, Emmett RL, Wespestad VG (2007) Recent pre-recruit Pacific hake (Merluccius productus) occurrences in the northern California Current suggest a northward expansion of their spawning area. Calif Coop Ocean Fish Invest Rep 48:215-229

Platt T, Fuentes-Yaco C, Frank KT (2003) Spring algal bloom and larval fish survival. Nature 423:398-399

Ralston S, Bence JR, Eldridge MB, Lenarz WH (2003) An approach to estimating rockfish biomass based on larval production, with application to Sebastes jordani. Fish Bull 101:129-146

Richardson SL (1973) Abundance and distribution of larval fishes in waters off Oregon, May-October 1969, with emphasis on the northern anchovy, Engraulis mordax. Fish Bull 71:697-711

Richardson SL, Pearcy WG (1977) Coastal and oceanic larvae in an area of upwelling off Yaquina Bay, Oregon. Fish Bull 75:125-145

Shanks AL, Eckert GL (2005) Population persistence of California Current fishes and benthic crustaceans: a marine drift paradox. Ecol Monogr 75:505-524

Shenker JM (1988) Oceanographic associations of neustonic larval and juvenile fishes and Dungeness crab megalopae off Oregon. Fish Bull 86:299-317

Sherman K, Lasker R, Richards W, Kendall AW Jr (1983) Ichthyoplankton and fish recruitment studies in large marine ecosystems. Mar Fish Rev 45:1-25

Ureña HM (1989) Distribution of the eggs and larvae of some flatfishes (Pleuronectiformes) off Washington, Oregon and northern California, 1980-1983. MS thesis, Oregon State University, Corvallis, OR

Submitted: June 25, 2007; Accepted: April 25, 2008

Proofs received from author(s): August 20, 2008 